still another distinct type, the post-critical regime. At extremely high Reynolds' numbers the flow becomes further complicated by the production of certain sound waves.

A final point of interest here is the possibility of using the vertical section of the graph in the production of accurately constant rates of flow in instrumental and process controls, as a very great change is required in the overall head loss to produce a small change in the rate of flow.

It is hoped to publish a fuller report than this elsewhere.

Alfred H. Nissan.

Department of Oil Engineering and Refining, University, Birmingham, 15.

${ }^{1}$ Nissan, A. H., Nature, 148, 503 (1941).

\section{A Late-Glacial Flora in Co. Monaghan, Ireland}

IN 1715 the molar teeth and other remains of a mammoth were discovered to the east of Belturbet, Co. Cavan ${ }^{1}$. In 1940 a site in the townland of Drumurcher, Co. Monaghan, where near a mill there was a small alluvial flat, was tentatively identified as the place of the original find.

The alluvial flat, which lay between a ridge of rock and a drumlin, was covered by a layer of earth and small stones, certainly disturbed. Under the earth was a layer of sandy silt and below this was a fine river gravel rich in plant debris, including many Corylus nuts and some tree stems. Little pollen of the pine but abundant pollen of the alder was found

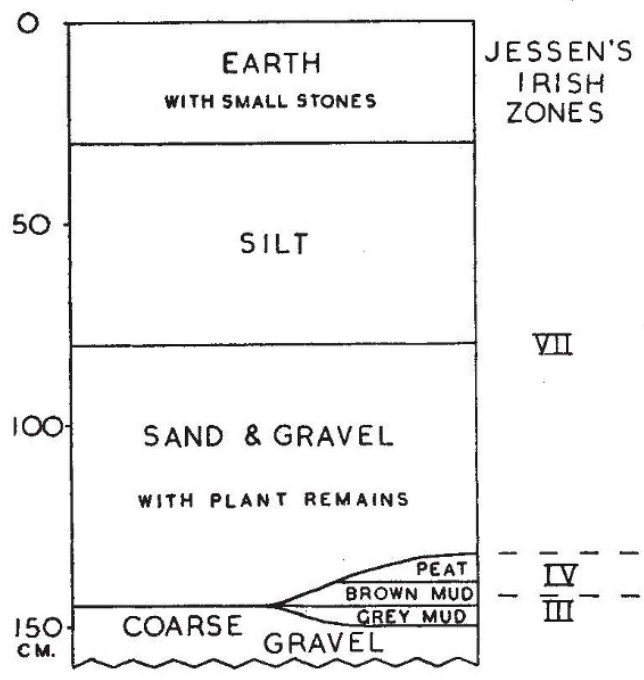

in the silt and the gravel. These deposits should, therefore, have been laid down after the beginning of Jessen's Irish Zone VII ${ }^{2}$. In places the gravel rested on a fine-grained peat rich in Salix leaves and containing also remains of Betula spp., Potamogeton spp., Carex spp., Scirpus lacustris, etc. Only pollen of the birch, pine and willow was found in the peat; it should, therefore, belong to Jessen's Irish Zone IV. Downwards the peat passed over into a brown mud; this in turn became grey in colour and rich in sand. The grey mud rested on a coarse river gravel without plant remains; the bottom of the gravel was not reached. In the muds, tree pollen was very scanty.
In places the upper gravel lay on the muds or directly on the lower gravel. The stratigraphy, which is illustrated in the diagram, agreed with that outlined in the original description.

The grey mud was rich in plant remains, among which the following plants were noted-Arenaria spp., Armeria vulgaris, Dryas octopetala, Oxyria digyna, Salix herbacea and Thalictrum alpinum. Dryas octopetala excepted, all these plants were previously found in a solifluxion deposit at Ballybetagh, Co. Dublin $^{3}$. With this deposit, associated with a local glaciation in the Wicklow Mountains ${ }^{4}$, the grey mud at Drumurcher is presumably contemporaneous. The Drumurcher site is about three hundred feet above sea-level. The presence of the small-leaved arctic form of Dryas octopetala in Co. Monaghan supports Jessen's suggestion that these Irish late-glacial deposits may be contemporaneous with the upper Dryas clay of Denmark. Though no traces of mammoth were found in 1940 , the resemblance of the flora of the grey mud to that associated with mammoth remains at Borna ${ }^{5}$ is worth noting.

Thanks are due to Mr. J. Andrews, the tenant of the site, for his co-operation, and also to $\mathrm{Mr}$. A. Farrington and Mr. A. M. Gwynn for their assistance in the field. The work was made possible by a grant from the Royal Irish Academy, in the Proceedings of which a full report will be later published.

\section{Iveagh Geological Laboratory, Trinity College, Dublin. March 31.}

${ }^{1}$ Nevile, Phil. Trans. Roy. Soc., 29 (1715).

${ }^{2}$ Mahr, A., Proc. Prehist. Soc., Paper 11 (1937).

3 Jessen, K., and Farrington, A., Proc. Roy. Irish Acad., B, 44 (1938).

- Farrington, A., Proc. Roy. Irish Acad., B, 42 (1934).

s Weber, C. A., Abhandl. Naturwiss. Ver. Bremen, 23 (1914).

\section{Russian for Scientific Workers}

There must be many scientific workers who would like to learn Russian if facilities were available, and there are certainly some excellent schools of Russian in Great Britain which would offer facilities. The most useful course would be one which would enable a student to read a Russian scientific paper with the aid of a dictionary and not too great an expenditure of time : on a foundation of this sort, a fuller and more general knowledge of the language could, if circumstances permitted, be developed.

The School of Slavonic and East European Studies of the University of London is making a start with a beginners' class open to any student, and as an act of marked generosity, given without fee to persons employed by the University or its institutions in teaching or administrative posts. Other courses are arranged elsewhere.

The purpose of this letter is to ask whether there are groups of scientific workers who would like to learn Russian, if the necessary arrangements could be made. There seems little doubt that the teaching could be provided in many cases at least, and if one knew the extent of the unsatisfied demand, it would be possible to set about meeting it. I should welcome any suggestions or comments.

Ministry of Information,

E. J. Russeli.

London, W.C.1. 